\title{
ACUTE HEPATITIS B IN A PATIENT PREVIOUSLY POSITIVE FOR ANTIBODY TO SURFACE ANTIGEN (ANTI-HBS) DETERMINED BY RADIOIMMUNOASSAY. CASE REPORT AND REVIEW OF THE LITERATURE
}

Edna STRAUSS, Amadeo SAEZ-ALQUezar, Augusta TAKEDA and Luiz Caetano da SILVA

\section{S U M M A R Y}

The determination of anti-HBs as a screening test before vaccination has been advisable in order to encounter immune individuals that don't need to receive vaccine protection. A case-report is presented and three other cases are reviewed from the literature. Anti-HBs was positive in these health-care personnels that developped typical acute $\mathrm{B}$ hepatitis. Different subtyping involving the $\mathrm{d} / \mathrm{y}$ determinants were found in the first case, but false-positive anti-HBs even with high titres, determined by RIA, were found in the other cases. Concomitant determination of anti-HBc or absence of screening tests seem to be more reasonable policies until a low-cost and risk-free vaccine is produced.

\section{N T R O D U G T I O N}

Hepatitis $B$ is a widespread infection all over the world. Hospital personnels as well as drug addicts and male homosexuals are the most important groups with the higher risk of getting the infection. This high risk population, more frequently in contact with the $B$ virus, cain develop a subclinical infection, which would naturally protect them against hepatitis B. Following this reasoning and taking in account that $B$ vaccine, made up of human serum, is expensive and not entirely free of eventual desease transmission, the determination of antiHBs as a screening test pre-vaccination would be advisable, and has been recomended by many Authors 7,8.

Herein a case report of a physician who already had anti-HBs in the serum and developed an acute $B$ hepatitis is described.

\section{CASE REPORT}

E.S., female, 40 years old, physician. The first determination of virus $B$ markers was made in April 1981 during a research screening in hospital personnel 12 and at that time her serum was positive for anti-HBs. Contamination occurred in the seventeenth of March 1983, by needle stick, while taking blood sample from a HBsAg positive and also $\mathrm{HBeAg}$ positive patient with persistent chronic hepatitis. Preventive measures, such as pos-exposure vaccination or administration of hyperimmune gammaglobulin, were not carried out. In the $23^{\text {rd }}$ of June symptoms of dizziness and weakness appeared, being associated with coluria in the 28th, when blood samples were taken for transaminases determinations. As they were above 10 times the upper normal limit a diagnosis of acute hepatitis was made and serum taken for viral markers determinations.

Symptoms persisted and worsened in the following weeks with deep jaundice, intense anorexia and weight loss. Liver was palpable $2 \mathrm{~cm}$ bellow the right costal margin, but spleen was not detectable. Sequential laboratorial data are summarized in Table $I$ and Graphic 1 illustrates the evolution of main parameters.

Complete recovery with negativation of the HBsAg was achieved after 12 weeks and one

Reprints: Dra. Edna Strauss - Unidade de Fígado, Faculdade de Medicina da USP. Av. Dr. Arnaldo, 455 - 3.0 andar. CEP 01246 - São Paulo, Brasil 
STRAUSS, E.; SAEZ-ALQUÉZAR, A.; TAKEDA, A. \& SILVA, L. C. da - Acute hepatitis B in a patient previously positive for antibody to surface antigen (anti-HBs) determined by radioimmunoassay. rature. Rev. Inst. Med. trop. São Paulo 27:258-263, 1985

year after (August/84) biochemical examinations re-assured this recovery. Virus B markers, determined by Enzymeimmunoassay (ÉLISA), showed HBsAg negative and both anti-HBs and
anti-HBc positive. Re-testing the serum taken at the onset of acute hepatitis the anti-HBs remained positive by RIA but it turned to be negative by ELISA.

T A B I E I

Laboratorial data of the case-report 1983

\begin{tabular}{|c|c|c|c|c|c|c|c|c|c|c|c|c|}
\hline & & & & \multicolumn{4}{|c|}{1900} & \multicolumn{5}{|c|}{1984} \\
\hline Exam & $06 / 28$ & $07 / 05$ & $07 / 12$ & $07 / 19$ & $07 / 29$ & $08 / 12$ & $08 / 26$ & $09 / 09$ & $09 / 23$ & $08 / 14$ & $\begin{array}{l}\text { Upper } \\
\text { mal }\end{array}$ & $\begin{array}{l}\text { nor- } \\
\text { values }\end{array}$ \\
\hline ALT & 645 & 711 & 1052 & 370 & 277 & 225 & 62 & 16 & 08 & 05 & $25 u$ & ur \\
\hline AST & 294 & 496 & 798 & 440 & 551 & 247 & 54 & 15 & 11 & 10 & & UI \\
\hline GGT & 17 & 21 & 16 & & 30 & 28 & & & & 07 & $18 \mathrm{u}$ & $\mathrm{UI}$ \\
\hline T. Bil. & 1,46 & 2,98 & 15,48 & 20,51 & 17,16 & 6,08 & 2,82 & 2,37 & 1,33 & 0,5 & $1,2 \mathrm{n}$ & $\mathrm{mg} \%$ \\
\hline Dir. Bil. & 0,94 & 1,75 & 10,23 & $15 ; 83$ & 14,25 & 5,10 & 2,60 & 1,35 & 1,16 & 0,4 & $0,4 \mathrm{~m}$ & $\mathrm{mg} \%$ \\
\hline $\begin{array}{l}\text { Prothr. Activity } \\
\text { Alb. }\end{array}$ & $\begin{array}{l}99 \% \\
3.8\end{array}$ & $92 \%$ & $98 \%$ & $100 \%$ & - & $100 \%$ & & & & & $80-100 \%$ & \\
\hline Alpha 1 G & $\begin{array}{l}3,6 \\
0,36\end{array}$ & & & & & & 3,52 & & & 3,92 & 3,5 to & $5,2 \mathrm{~g}^{0} \%$ \\
\hline Alpha $2 \mathrm{G}$ & 0,48 & & & & & & 0,36 & & & 0,25 & 0,1 to & $0,3 \mathrm{~g} \%$ \\
\hline Beta G & 0,66 & & & & & & 0,55 & & & 0,70 & 0,4 to & $0,8 \mathrm{~g} \%$ \\
\hline Gama $\mathbf{G}$ & 1,20 & & & & & & 0,84 & & & 0,87 & 0,5 to & $0,9 \mathrm{~g} \%$ \\
\hline FBBsAg & $(+)$ & & & & & & 1,63 & & & 1,26 & 0,8 to & $1,5 \mathrm{~g} \%$ \\
\hline Anti-HBc & $(+)$ & & & & & & & $(+)$ & 一 & - & & \\
\hline Anti-HBs & $(+)$ & & & & & & & & & $(+)$ & & \\
\hline $\mathrm{HBe} \quad \mathrm{Ag}$ & $(+)$ & & & & - & $(-)$ & & & & (十) & & \\
\hline Anti-HBe & $(-)$ & & & & & & & & & & & \\
\hline
\end{tabular}

$\mathrm{ALT}=$ Alanineaminotransferase

AST = Aspartatoaminotransferase

GGT = Gamaglutamiltransferase

T. Bil. = Total bilirubin

Dir. Bil. = Direct bilirubin

Prothr. Activity $=$ Prothrombin Activity

Alb. = serum albumin

\section{COMMENTS}

It is well known that in the course of a typical virus $B$ hepatitis the positivity of antiHBc indicates present infection whereas the development of anti-HBs, after 8 to 12 weeks, is the usual resolution of the disease. This development means not only cure but also natural immunological prevention against new exposures to the virus.

The vaccine, prepared from the serum of hepatitis $B$ carriers and having only surface antigen (HBsAg) with no Dane particles, will provide the formation of anti-HBs and this surface antibody protects against the disease. Although subtypes of virus $B$ have been describ. ed, cross protection was also demonstrated after vaccination 13 .

Based on these facts, simultaneous occurrence of HBsAg and anti-HBs should never happen. Nevertheless this concomitance has been reported $1,3,5,10,14,15$. In the earlier reports 5,10 five cases out of seven were blooddonors apparently healthy 'while the other two were sick patients; one in hemodialysis and the other with chronic active hepatitis. These Authors subtyped both anti-HBs and HBsAg pointing out that the paradoxal combination involved the $d / y$ system of determinants. At that time they formulated two hypothesis trying to ex. plain these findings. In the first one, a infection with one subtype develops a tolerant car rier state which is followed by another infection with a different subtype eliciting an immune response. In the second one, a vertical transmission in early life could lead to a tolerance to HBsAg of a particular subtype and a re-infection by another subtype would develop immunological reaction with the appearance of anti-HBs. In Foutch's series ${ }^{3}$ the antibody has never appeared before the antigen. Although clinical data about all the patients are not avai. lable in these laboratory investigations, it was 
VALUES OF TOTAL AND DIRECT BILIRUBINS IN mg\%

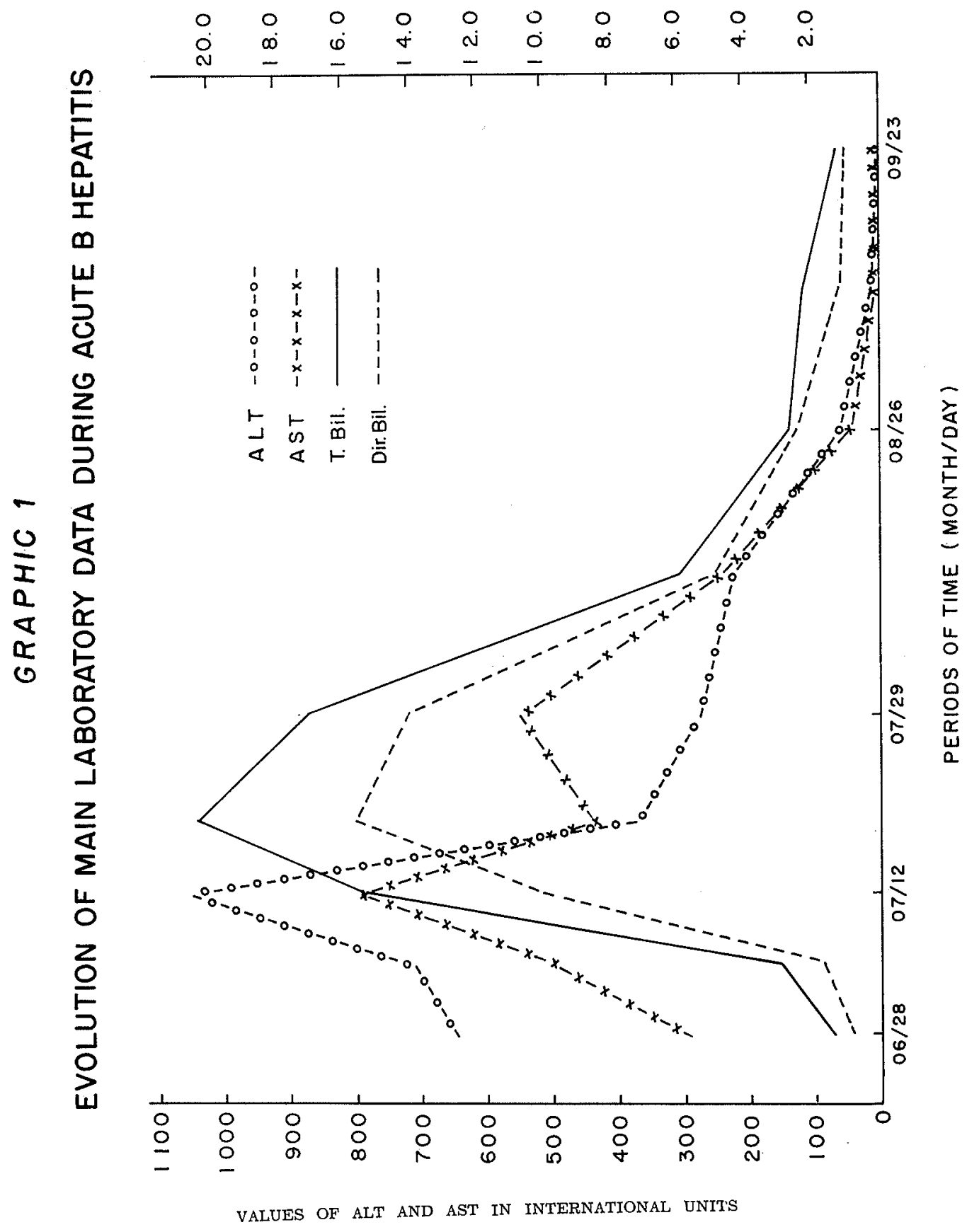

shown that seven of the 13 patients had renal diseases, six of whom in hemodialysis. TABOR 14 describes a chronic HBsAg carrier and a Kaposi's sarcoma among his three patients and the reported case of BALAQUE' 1 had a multi- systemic disease. Besides the conclusion that anti-HBs can coexist with HBsAg, these reports support the possibility of an atypical immunological response to hepatitis $B$ virus, with monotypic anti-HBs failing to protect 
STRAUSS, E.; SAEZ-ALQUEZAR, A.; TAKEDA, A. \& SILVA, L. C. da - Acute hepatitis B in a patient previously positive for antibody to surface antigen (anti-HBs) determined by radioimmunoassay. Case report and review of the lite rature. Rev. Inst. Med. trop. São Paulo 27:258-263, 1985.

T A B L E II

Case-reports of health-care workers Anti-HBs positive who posteriorly developed acute $B$ hepatitis

\begin{tabular}{|c|c|c|c|c|}
\hline $\begin{array}{ll}\text { Case report } \\
\text { Data }\end{array}$ & KOZIOL, D. E. et al. & $\begin{array}{l}\text { SHERERTA, R. J. \& } \\
\text { HOOFNAGLE, J. H. }\end{array}$ & $\begin{array}{l}\text { LINNEMANN, C. C. } \\
\& \text { ASKEY, P. A. }\end{array}$ & STRAUSS, E. et al. \\
\hline Reference & J. Imunol. 117: 2260 & $\begin{array}{l}\text { N. EngI. J. Med. } \\
\text { 309: } 1519\end{array}$ & Lancet 11: 346 & \\
\hline Year & 1976 & 1983 & 1984 & 1984 \\
\hline $\begin{array}{l}\text { Sex and age of } \\
\text { patients }\end{array}$ & Male / 51 & Female / 38 & Female / - & Female / 40 \\
\hline Profession & Dentist & Nurse & Phlebotomist & Physician \\
\hline $\begin{array}{ll}\text { Previous Anti-HBs } \\
\text { Anti-HBc } \\
\end{array}$ & $+1-$ & $+1-$ & $+1-$ & $+/$ not done \\
\hline Method used & $\begin{array}{l}\text { Passive hemaglu- } \\
\text { tination }\end{array}$ & RIA & RIA & RIA \\
\hline $\begin{array}{l}\text { Type/time of } \\
\text { contamination }\end{array}$ & $\begin{array}{l}\text { Serum of hepatitis } \\
6 \text { months earlier }\end{array}$ & $\begin{array}{l}\text { Needle-punoture } \\
2 \text { months earlier }\end{array}$ & $\begin{array}{l}\text { Needle-puncture } \\
4 \text { months earlier }\end{array}$ & $\begin{array}{l}\text { Needle-puncture } \\
3 \text { months earlier }\end{array}$ \\
\hline $\begin{array}{l}\text { Anti-HBs at the } \\
\text { onset of hepatitis }\end{array}$ & Present & Present & Absent & Present* \\
\hline Values of ALT & $1198 \mathrm{u} / 1$ & $2570 \mathrm{u} / 1$ & - & $1052 \mathrm{u} / \mathrm{I}$ \\
\hline $\begin{array}{l}\text { Values of total } \\
\text { bilirubin }\end{array}$ & $24 \mathrm{mg} \%$ & $8,8 \mathrm{mg} \%$ & - & $20,5 \mathrm{mg} \%$ \\
\hline Outcome & Complete recovery & - & $C_{1}$ & Complete recovery \\
\hline Hypothesis & $\begin{array}{l}\text { Different sub-types } \\
\text { of Anti-HBs }\end{array}$ & $\begin{array}{l}\text { Anti-HBs blocked } \\
\text { only by dithio- } \\
\text { threitol }\end{array}$ & $\begin{array}{l}\text { Inespecific IgM } \\
\text { Anti-HBs }\end{array}$ & $\begin{array}{l}\text { * Negative when } \\
\text { re-tested by ELISA }\end{array}$ \\
\hline
\end{tabular}

against infection by a different subtype. If this happens only in persons with peculiar immunological responses, suffering from renal or other diseases is still to be demonstrated.

A different situation is herein reported. In this case report, as in three others of the literature $4,6,11$, the antibody and not the antigen was detected from eight months to three years before the exposition to hepatitis $B$ virus had occurred. Although aware of the risk of acquiring hepatitis by needle stick, the three hospital personnels did not take preventive measures believing that the anti-HBs in their serum indicated that they were immune against $B$ hepatitis. Table II summarizes the main data from the three cases reported and includes the one herein described as the fourth.

The first case-report 4 was published in 1976, still using passive hemagglutination for the detection of anti HBs. No effect on anti-y reagent was demonstrated when the 8 categories of this antibody were subtyped in the serum taken before the acute $B$ infection. This anti-y reaction appeared in the serum after clinical hepatitis. The two other cases were mentioned in letters to the editors while discussing screening before vaccination for $B$ hepatitis. They are more recent cases and anti-HBs determinations were made by RIA. As a common feature, these two cases and the first one were negative for anti-HBc (the core antibody of $B$ hepatitis). In the case-report of SHERERTZ \& HOOFNAGLE 11 the anti-HBs was not blocked by any of the eight known subtypes of HBsAg but only by dithiothreitol, while LINNEMANN \& ASKEY ${ }^{6}$ suggested that the anti-HBs of their case was probably IgM.

Low-titre of anti-HBs, defined as a ratio less than 10 times the cutt-off when radioimmunoassay is used, could account for false-positive reactions. Nevertheless, high titre Anti-HBs 
STRAUSS, E.; SAEZ-ALQUÉZAR, A.; TAKEDA, A. \& SILVA, L. C. da - Acute hepatitis B in a patient previously positive for antibody to surface antigen (anti-HBs) determined by radioimmunoassay. Case report and review of the literature. Rev. Inst. Med. trop. São Paulo 27:258-263, 1985.

were observed in the third case-report proving that titring alone is not safe.

In this case-report, before determining subtypes, it was decided to re-test the serum samples for anti-HBs by another sensitive method, ELISA, and surprisingly the result was negative. Such fact would support two possibilities: a) the positivity by RIA was a false-positive reaction; b) the negativity by ELISA was due to less sensibility of this method. Studies from the literature ${ }^{9}$ are not in favor of this second hypothesis, showing equal sensibility for RIA and ELISA.

Finally we should say that, although rare, false-positive anti-HBs or monotypic non-protective anti-HBs have been described when screening before hepatitis $\mathrm{B}$ vaccination. The policy of screening only for anti-HBs, in order to consider people from high risk groups as immune, should be seriously questioned. Associated positivity of anti-HBc seems to indicate real immunity and is easier to be performed than the "specificity testing" for anti-HBs, as proposed by FIEDLER 2. The determination of the three markers (anti-HBs, anti-HBc and HBsAg) besides being more expensive, can be refused by some physicians and healthy-care workers. A practical alternative is not to screen at all, even with the possibility of administrating the vaccine to some immune persons and to assymptomatic carriers. But this policy is also expensive and cost effectiviness should be calculated, since we still have a blood-borne first generation vaccine. We hope technological advances in the near future will permit low-cost and free-risk vaccinations for $B$ virus hepatitis.

\section{RESUMO}

Hepatite aguda $B$ em paciente previamente positiva para o anticorpo de superfície (anti-HBs) determinado por radioimunoensaio. Relato de caso e revisão da literatura

A determinação do anticorpo de superfície contra a hepatite $\mathrm{B}$ (anti-HBs) precedendo a vacinação tem sido aconselhada com o intuito de encontrar indivíduos já imunes, para os quais esta administração seria desnecessária.

Um caso clínico é aqui apresentado, juntamente com a revisão de três casos mencionados na literatura, nos quais o anti-HBs foi po. sitivo em pessoal hospitalar, o que justificou sua não vacinação e ausência de medidas preventivas face contaminação pelo vírus $B$. Malgracio esta aparente proteção pela presença do anti-HBs eles desenvolveram hepatite aguda típica pelo vírus $B$.

No primeiro caso da literatura a subtipar gem revelou que o anti-HBs do passado e a infecção atual tinham determinantes $d / y$ diferentes. Entretanto, os outros casos relatados mostravam ser o anti-HBs, dosado por radioimunoensaio (RIE), um falso positivo. Em nosso relato de caso o soro colhido no início da hepatite aguda foi re-testado por dois métodos diferentes e igualmente sensíveis. Observou-se persistência de positividade pelo RIE porém negatividade pelo enzimaimunoensaio (ELISA)

A determinação concomitante de anti-HBs e anti-HBc ou ainda dos três marcadores é uma das alternativas propostas, enquanto que outra conduta seria a não realização de qualquer teste pré-vacinação. Acreditamos que o desenvolvimento tecnológico propiciará produção de vacinas menos dispendiosas e totalmente isentas de risco em futuro próximo.

\section{REFERENCES}

1. BALAGUE, F.; HUMAIR, L. \& TORRENTÉ, A. - Périarterite moueuse chez un patient porteur simultanément des antigénes HBs, HBc et HBe et d'anticorps antiHBs. Schweiz. Med. Wochens. 34: 1201-1205, 1983.

2. FIEDLER, H. - Diagnostic limitations of antibody to hepatitis B surface antigen. N. Engl. J. Med. 310: $1672,1984$.

3. FOUTCH, P. G.; CAREY, W. D.; TABOR, E.; CIANFLOCCO, A. J.; NAKAMOTO, S.; SMALLWOOD, L. A. \& GERETY, R. J. - Concomitant hepatitis B surface antigen and antibody in thirteen patients. Ann. Int. Med. 99: 460-463, 1983.

4. KOZIOL, D. E.; ALTER, H. J.; KIRCHNER, J. P. \& HOLLAND, P. V. - The development of HBsAg positive hepatitis despite the previous existence of antibody to HBSAg. J. Immunol. 117: 2260-2262, 1976.

5. LE BOUVIER, G. L.; CAPPER, R. A.; WILLIAMS, A. E.; PELleTIER, M. \& KATZ, A. J. - Concur. rently circulating hepatitis $B$ surface antigen and heterotypic anti-HBs antibody. J. Immunol. 117: 2262$2264,1976$.

6. LINNEMANN, C. C. \& ASKEY, P. A. - Susceptibility to hepatitis $B$ despite high titre anti-HBs antibody, Lancet 1: $346-347,1984$. 
STRAUSS, E; SAEZ-ALQUEZAR, A.; TAKEDA, A. \& SILVA, L. C. da - Acute hepatitis B in a patient previously positive for antibody to surface antigen (anti-HBs) determined by radioimmunoassay. Case report and review of the lite. rature. Rev. Inst. Med. trop. São Paulo 27:258-263, 1985.

7. MENDONÇA, J. S. \& AMATO NETO, V. - Orientação para uso da vacina preventiva da hepatite por virus B. Rev. Paul. Med. 101: 25-26, 1983.

8. MULLEY, A. G.; SILVERSTEIN, M. D. \& DIENSTAG, J. I. - Indications for use of hepatitis $B$ vaccine, based on cost-effectiveness analysis. N. Engl. J. Med. 307: 644,1982 .

9. POLESKY, H. F. - Serologic tests in viral hepatitis. In: HOMBURGER, H. A. \& BATSAKIS, J. G. (eds.). CLINICAL LABORATORY ANNUAL. V. I. NeW York, Appleton-Century-Crafts, 1982, 105-118.

10. SASAKI, T.; OHKUBO, Y.; YAMASHITA, Y.; IMAI, M.; MIYAKAWA, Y. \& MAYUMI, M. - Co-occurrence of hepatitis B surface antigen of a particular subtype and antibody to a heterologous subtypic specificity in the same serum. J. Immunol. 11\%: 2258-2259, 1976.

11. SHERERTZ, R. J.; SPINDEL, E. \& HOOFNAGLE, J. H. - Antibody to hepatitis B surface antigen may not always indicate immunity to hepatitis $B$ virus infection. N. Engl. J. Med. 309: 1519, 1983.
12. STRAUSS, E.; MAFFEI JR., R.; SA, M. F. G.; DUTRA, A. P. \& TAKEDA, A. - Incidência de HBsAg e Anti-IHBs. Irrequiencia de antígeno de superfície da hepatite $B$ e de seus anticorpos detectados por radioimunoensaio em pessoal hospitalar. Rev. Inst. Med. trop. São Paulo 25: 246-253, 1983.

13. SZMUNESS, W.; STEVENS, C. E.; HARLEY, E. J.; ZANG, E. A.; ALTER, H. J.; TAYLOR, P. E.; DeVERA, A.; CHEN, G. T. S. \& LELLNER, A. - And the dialysis vaccine trial study group. Hepatitis $\mathbf{B}$ vaccine in medical staff of hemodialysis units. $N$. Engl. J, Med. 307: 1481-1486, 1982.

14. TABOR, E.; GERETY, R. J.; SMALLWOOD, L. A. \& BARKER, L. F. - Coincident hepatitis $B$ surface anti gen and antibodies of different subtypes in human serum. J. Immunol. 118: 369-370, 1977.

15. TELISCHI, M.; STEIGMANN, F.; CANLAS, N.; FOEMMEL, R.; DECKER, R. \& LING, C. - Incidence of HBsAg, anti-HBs and subtypes ad and ay in a ge neral hospital. Amer. J. Gastroenterol. 6\%: 449-455, 1977.

Recebido para publicação em 16/10/1984. 